\title{
Characterization of grape phenolic compounds of 'Carignan' grapevines grafted onto 'Paìs' rootstock from Maule Valley (Chile): Implications of climate and soil conditions
}

\author{
Gastōn Gutiērrez-Gamboa ${ }^{1}$, Marioli Carrasco-Quiroz², Nicolās Verdugo-Vásquez ${ }^{3}$, Irina Díaz-Gálvez ${ }^{4}$, \\ Teresa Garde-Cerdān ${ }^{1}$, and Yerko Moreno-Simunovic ${ }^{2 *}$ \\ ${ }^{1}$ Instituto de Ciencias de la Vid y del Vino (CSIC-CAR-UR), Ctra. de Burgos km 6, 26007 Logroño, España. \\ ${ }^{2}$ Universidad de Talca, Facultad de Ciencias Agrarias, Av. Lircay S/N, Talca, Chile. *Corresponding author (ymoreno@utalca.cl). \\ ${ }^{3}$ Instituto de Investigaciones Agropecuarias, INIA Intihuasi, Colina San Joaquín s/n, P.O. Box 36-B, La Serena, Chile. \\ ${ }^{4}$ Instituto de Investigaciones Agropecuarias, INIA Raihuén, Casilla 34, San Javier, Chile.
}

Received: 23 January 2018; Accepted: 14 May 2018; doi:10.4067/S0718-58392018000200310

\begin{abstract}
Certain grape (Vitis vinifera $\mathrm{L}$.) varieties overseen for decades by the Chilean wine industry have emerged as the 'Carignan'. 'País' has not had this resurgence and its production is sold for a price below the national average, negatively affecting the economy of small producers of the Maule Valley (Chile). The aim was to study the grape phenolic composition of 'Carignan' grapevines grafted onto 'País' rootstock according to climate and soil conditions. Sites were located in Valdivia (Val), Loncomilla (Lon), Melozal (Mel), and Huerta de Maule (Hdm) situated in Maule Valley. Phenolic compounds in grapes were analyzed by HPLC. The results showed that soil and climate conditions affected the accumulation of soluble solids, weight of 100 berries and most of the anthocyanins, flavonols and flavanols. Total anthocyanins content in grapes varied from 1393.05 to $1856.03 \mathrm{mg} \mathrm{kg}^{-1}$ (Val and Mel sites, respectively), while total flavonols content ranged from 124.17 to $218.93 \mathrm{mg} \mathrm{kg}^{-1}$ (Val and Lon, respectively). Total flavanols concentration varied from 86.85 to $158.13 \mathrm{mg} \mathrm{kg}^{-1}$ (Lon and Val), while total content of hydroxycinnamic acids varied from 23.91 to $34.84 \mathrm{mg} \mathrm{kg}^{-1}$ (Mel and Hdm). Location conditioned grape flavonoid composition of 'Carignan' grapevines grafted onto 'País'. The use of an ancient variety as a rootstock ('País') on a variety with a great oenological potential ('Carignan'), could be a viticultural tool to improve the income of the small wine-growers of the Maule Valley, without affecting phenolic composition in grapes.
\end{abstract}

Key words: 'Carignan' grafted onto 'País', location, phenolic compounds, rainfed viticulture, Vitis vinifera.

\section{INTRODUCTION}

During the last years, certain minority grapevine (Vitis vinifera L.) varieties overseen for decades by the Chilean wine industry have emerged mainly due to their oenological potential and the changes in wine consumer's habits. This resurgence has allowed the economic and social recovery of a part of the small wine-growers of the Maule Valley, who cultivate the oldest grapevine Chilean varieties. Carignan grape variety is one of those minor cultivars that has had a major resurgence. 'Carignan' wines, mostly are sold under the collective brand "VIGNO", within which are several of the most prestigious Chilean wineries. In contrast, 'País' has not had the expected resurgence, and its production is sold at a price well below the Chilean national average. Chilean wine industry has made some efforts to diversify the 'País' 
wine production. In this sense, due to the oenological characteristics of the variety, its production has been destined for the elaboration of rosé and sparkling wines.

Carignan and País varieties, make up a unique heritage in Chilean winemaking, which has given a new identity to the country in the world wine scenario. These grapevine varieties have been cultivated mostly by small wine-growers located in the Maule, Itata, and Bío Bío Valleys, the largest wine producing area of Chile, with unirrigated vines trained to a traditional bush system. In particular, Maule Valley holds approximately 700 ha of a total of 843 ha of 'Carignan' (83\%), and around 4995 ha of a total of 12520 ha of 'País' (38 \%) planted in the country (SAG, 2015).

'País' is a very rustic variety that tolerates nematodes and other soilborne pests and that under rainfed conditions performs better than most of the V. vinifera varieties. For the aforementioned reasons, and due to the low price of its grapes, it has been used as a rootstock for other varieties when retrofitting a vineyard (Moreno and Vallarino, 2011; Gutiérrez-Gamboa et al., 2018a; 2018b). The reports about 'Carignan' viticultural behavior under dry farmed conditions are scarce and for the aforementioned the aim of this work was to study the grape phenolic composition of 'Carignan' grapevines grafted onto 'País', coming from four different wine-growing sites in the Maule Valley (Chile), varying in their climatic and soil conditions.

\section{MATERIALS AND METHODS}

\section{Study site, plant material, harvest, soil, and climate conditions}

An experimental research was performed along the Maule Valley, Maule Region (Chile) during the 2015 vintage. Four different sites from the Maule Valley were selected for this study, based on geological and geomorphological information stated by Martínez-Gil et al. (2018). 'Carignan' vineyards were located in Valdivia (Val), Loncomilla (Lon), Melozal (Mel), and Huerta de Maule (Hdm) (Table 1). In these vineyards, Carignan grapevines were grafted onto País rootstock. In each of the sites was chosen a representative vineyard, where three replicates were arranged randomly within the vineyard, accounting around 18-22 grapevines per replicate. All selected sites had old grapevines (>30 yr old) that were not irrigated, trained to a bush system, growing in good phytosanitary conditions and with an active leaf surface area during the season. Information about vineyard area, number of plants per hectare, yield, vineyard age, nutritional management, and viticultural practices for each site is stated in the manuscript of Gutiérrez-Gamboa et al. (2018a). Vineyard selection, harvest procedure and soil characterization were made according to the stated by Martínez-Gil et al. (2018). Information about climatic variables was recorded in situ, from temperature and RH sensors (HOBO Pro v2, Onset Computer Corporation, Bourne, Massachusetts, USA) located at the beginning of the row at $1.5 \mathrm{~m}$ above the soil. Location, water holding capacity, and seasonal temperature are shown in Table 1.

\section{Analysis of technological maturity}

Musts were physicochemically characterized by determining soluble solids ( $\left.{ }^{\circ} \mathrm{Brix}\right), \mathrm{pH}$, and total acidity according to the methodology established by OIV (2003). Must yeast assimilable N (YAN) was determined according to the Sörensen (1907) methodology. Samples obtained from each site were taken in triplicate.

Table 1. Location, water holding capacity, oenological parameters and seasonal temperature from 'Carignan' vineyards grafted onto 'País' rootstock along Maule Valley (Chile): Valdivia (Val), Loncomilla (Lon), Melozal (Mel), and Huerta de Maule (Hdm).

\begin{tabular}{|c|c|c|c|c|c|c|c|c|c|c|}
\hline \multirow[b]{2}{*}{ Site } & \multirow[b]{2}{*}{ Location } & \multirow{2}{*}{$\begin{array}{c}\text { Water } \\
\text { holding } \\
\text { capacity }\end{array}$} & \multicolumn{5}{|c|}{ Oenological parameters } & \multicolumn{3}{|c|}{ Seasonal temperature } \\
\hline & & & ${ }^{\circ}$ Brix & $\mathrm{pH}$ & $\begin{array}{c}\text { Total } \\
\text { acidity* }\end{array}$ & YAN & $\begin{array}{l}\text { Weight of } 100 \\
\text { berries }\end{array}$ & Min & Max & Average \\
\hline & & $\mathrm{cm}$ & & & $\mathrm{g} \mathrm{L}^{-1}$ & $\mathrm{mg} \mathrm{L}^{-1}$ & $\mathrm{~g}$ & & ${ }^{\circ} \mathrm{C}$ & \\
\hline Val & 199269X, 6007477Y & 8.2 & $24.30 \pm 1.06 \mathrm{~b}$ & $3.60 \pm 0.05 b$ & $7.36 \pm 0.85 \mathrm{a}$ & $196.00 \pm 22.34 \mathrm{a}$ & $103.96 \pm 27.47 \mathrm{a}$ & 1.6 & 38.3 & 18.6 \\
\hline Lon & 235939X, 6057816Y & 10.8 & $24.57 \pm 0.55 b$ & $3.40 \pm 0.09 \mathrm{a}$ & $6.16 \pm 0.69 a$ & $197.00 \pm 11.36 \mathrm{a}$ & $141.59 \pm 27.91 \mathrm{ab}$ & 1.7 & 38.1 & 17.7 \\
\hline Mel & $240706 \mathrm{X}, 6040323 \mathrm{Y}$ & 8.6 & $26.23 \pm 0.15 c$ & $3.30 \pm 0.06 a$ & $6.73 \pm 0.53 a$ & $200.67 \pm 6.43 a$ & $150.12 \pm 17.19 b$ & 2.3 & 37.6 & 19.0 \\
\hline $\mathrm{Hdm}$ & 231116X, 6049957Y & 21.7 & $22.53 \pm 0.76 a$ & $3.41 \pm 0.10 \mathrm{a}$ & $6.33 \pm 0.17 \mathrm{a}$ & $198.33 \pm 10.41 \mathrm{a}$ & $165.86 \pm 16.95 b$ & -0.7 & 38.4 & 17.1 \\
\hline
\end{tabular}

All parameters are given with their standard deviation $(n=3)$.

For each parameter, different letters in the same column indicate significant differences $(\mathrm{p} \leq 0.05)$ among the sites.

*As g tartaric acid $\mathrm{L}^{-1}$ 


\section{Extraction of grape samples and non-anthocyanin compounds}

Grape extraction of the samples was performed according to the exposed by Portu et al. (2015). Around of $50 \mathrm{~g}$ of each frozen grape sample were immersed in $50 \mathrm{~mL}$ aqueous methanol solution $(50 \% \mathrm{v} / \mathrm{v})$ at $\mathrm{pH} 2$, which was adjusted with formic acid (> 96\%). Isolation of non-anthocyanin compounds from the samples was carried out according to the methodology exposed by Castillo-Muñoz et al. (2007). Extraction was performed on PCX SPE cartridges (500 mg, $6 \mathrm{~mL}$ Bond Elut Plexa, Agilent, Palo Alto, California, USA). The eluate containing the anthocyanin-free fraction was dried in a rotary evaporator at $35^{\circ} \mathrm{C}$ (Hei-VAP Advantage HL/G5, Heidolph, Schwabach, Germany) and re-solved in $1.5 \mathrm{~mL}$ $20 \%(\mathrm{v} / \mathrm{v})$ methanol aqueous solution. The anthocyanin free fraction was used to analyze non-anthocyanin compounds (flavonols, flavanols, and hydroxycinnamic acids).

\section{Analysis of phenolic compounds in grapes by HPLC}

The analysis of grape phenolic compounds was made using a liquid chromatograph Agilent 1260 Infinity, equipped with a diode array detector (DAD). Anthocyanins were analyzed by direct injection of $10 \mu \mathrm{L}$ of grape extract previously filtered (0.22 $\mu \mathrm{m}$, Chromafil PET 20/25, Machery-Nagel, Düren, Germany). Non-anthocyanin compounds were analyzed by injection of $20 \mu \mathrm{L}$ of anthocyanin-free grape fractions previously filtered. Separation was achieved on a reversed-phase column $(250 \times 4.0 \mathrm{~mm} ; 5 \mu \mathrm{m}$ packing $)$ with pre-column $(4 \times 4 \mathrm{~mm} ; 5 \mu \mathrm{m}$ packing; LiChrospher $100 \mathrm{RP}-18$, Agilent $)$, both thermostated at $40{ }^{\circ} \mathrm{C}$. A flow rate of $0.63 \mathrm{~mL} \mathrm{~min}^{-1}$ was established. Chromatographic conditions were based on CastilloMuñoz et al. (2007). The identification of all compounds was performed according to the retention times of pure compounds and the UV-Vis characteristics obtained from authentic standards or those published in previous studies (Lago-Vanzela et al., 2011). (-)-Epicatechin, (+)-catechin, quercetin, quercetin-3- $O$-glucoside, quercetin-3- $O$-galactoside, kaempferol, and myricetin standards were purchased from Sigma-Aldrich (St. Louis, Missouri, USA). Malvidin-3-O-glucoside, quercetin-3-O-glucuronide, procyanidin B1, procyanidin B2, (-)-epigallocatechin, and (-)-epicatechin gallate standards were purchased from Extrasynthèse (Genay, France). Compounds quantification was made using DAD chromatograms recorded at $520 \mathrm{~nm}$ (anthocyanins), $360 \mathrm{~nm}$ (flavonols), $320 \mathrm{~nm}$ (hydroxycinnamic acids), and $280 \mathrm{~nm}$ (flavanols) and the calibration graphs of the respective standards $\left(\mathrm{R}^{2}>0.999\right)$. Quantification of non-commercial compounds was made according to the calibration graphs of the most similar compounds. Hence, anthocyanins were expressed as $\mathrm{mg} \mathrm{kg}^{-1} \mathrm{of}$ malvidin-3-O-glucoside, flavonols were expressed as $\mathrm{mg} \mathrm{kg}^{-1}$ of quercetin-3-O-glucoside, and hydroxycinnamic acids were expressed as $\mathrm{mg} \mathrm{kg}^{-1}$ of trans-caftaric acid, procyanidins B1 and B2 were expressed as $\mathrm{mg} \mathrm{kg}^{-1}$ of catechin, while epicatechin-3-gallate was expressed as $\mathrm{mg} \mathrm{kg}^{-1}$ of epicatechin.

\section{Statistical analysis}

The statistical analysis of oenological parameters and phenolic compounds was performed using one-way ANOVA by Statgraphics Centurion XVI.I (The Plains, Virginia, USA). Differences between samples were compared using Duncan test at $95 \%$ probability level.

\section{RESULTS AND DISCUSSION}

\section{Grape oenological parameters}

Table 1 shows must oenological parameters and seasonal temperature from 'Carignan' vineyards grafted onto 'País' rootstock along Maule Valley (Chile): Valdivia (Val), Loncomilla (Lon), Melozal (Mel), and Huerta de Maule (Hdm). Significant differences were found in some oenological parameters among the different sites. However, total acidity and YAN content was not affected by the different locations. Thus, the grapes from Mel presented the highest ${ }^{\circ} \mathrm{Brix}$, while the samples collected from Hdm site, the lowest. The grapes from Val presented the highest pH. Weight of 100 berries in the samples harvested from Val was lower than in the grapes collected from Mel and Hdm sites. Probably, must oenological parameters were affected by the climatic conditions and soil characteristics of each wine-growing site. The low accumulation of soluble solids in Hdm grapes at harvest was probably due to the edafoclimatic characteristics of the site. Hdm presented the highest water holding capacity (WHC). Besides, in terms of climate, this site showed the lowest minimal and average seasonal temperature. Respect to the reported by Gutiérrez-Gamboa et al. (2018a) Hdm site presented lower Huglin's index (HI), accumulation of biologically effective degree days (BEDD), cool night index and 
mean temperature of the warmest month than the rest of the wine-growing sites. These results match to the reported in 'Carignan' vineyards from different valleys by Edo-Roca et al. (2013) and Martínez-Gil et al. (2018). In addition, it is probably that WHC affected grapevine vegetative development in Hdm site leading to a higher weight of 100 berries than Val, which presented the lowest WHC.

\section{Grape anthocyanins content}

Table 2 shows grape anthocyanins concentration from 'Carignan' vineyards grafted onto 'País' rootstock along Maule Valley (Chile). The major contributor to total anthocyanins in grapes was the non-acylated forms, varying from 910.48 to $1305.79 \mathrm{mg} \mathrm{kg}^{-1}$ (Val and Mel sites, respectively), followed by the coumaroylated forms, which ranged 409.25 to 456.03 $\mathrm{mg} \mathrm{kg}^{-1}$ (Val and Mel, respectively), being the acylated derivatives the minor forms varying, from 68.51 to $87.76 \mathrm{mg}$ $\mathrm{kg}^{-1}$ (Val and Mel, respectively). The major acylated form was the coumaroylated, which has already been described in ungrafted 'Carignan' grapes (Martínez-Gil et al., 2018). Malvidin-3-glucoside (glc) was the most abundant anthocyanin in 'Carignan' grapes varying from 536.54 to $799.08 \mathrm{mg} \mathrm{kg}^{-1}$ (Val and Mel sites, respectively). Total anthocyanins ranged from 1393.05 to $1856.03 \mathrm{mg} \mathrm{kg}^{-1}$ (Val and Mel sites, respectively). Most of the acetylated and coumaroylated anthocyanins was not affected by the location. However, the grapes from Val presented the lowest concentration of the most abundant anthocyanins such as delphinidin-3-glc and malvidin-3-glc, affecting negatively total anthocyanins content. This last site, presented the lowest water holding capacity. Thus, it was showed that soil and vintage condition were the most important variability factors compared to cultivar on anthocyanin content in grapevine berries (van Leeuwen et al., 2004). In addition, these authors showed that the impacts of climate and soil on anthocyanin concentration in grapes were greater than cultivar, and many of the analyzed variables were correlated with the intensity of vine water stress. Moreover, Andrés-de Prado et al. (2007) reported that the vineyards that presented the greatest water holding capacity, produced wines with lower color intensity and shade, as well as lower total phenolic composition and a smaller quantity of hydroxycinnamic acids.

Table 2. Grape anthocyanins content from 'Carignan' vineyards grafted onto 'País' rootstock along Maule Valley (Chile): Valdivia (Val), Loncomilla (Lon), Melozal (Mel), and Huerta de Maule (Hdm).

\begin{tabular}{|c|c|c|c|c|}
\hline & Lon & Mel & $\mathrm{Hdm}$ & Val \\
\hline & & 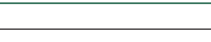 & & \\
\hline Df-3-Glc & $247.93 \pm 22.51 b$ & $231.65 \pm 5.88 b$ & $217.24 \pm 36.11 b$ & $150.89 \pm 40.02 \mathrm{a}$ \\
\hline Cn-3-Glc & $21.35 \pm 1.19 \mathrm{a}$ & $18.85 \pm 3.62 \mathrm{a}$ & $24.25 \pm 1.40 \mathrm{a}$ & $22.18 \pm 7.73 a$ \\
\hline Pt-3-Glc & $208.97 \pm 18.25 b$ & $200.46 \pm 5.72 b$ & $183.09 \pm 27.98 \mathrm{ab}$ & $140.61 \pm 41.58 \mathrm{a}$ \\
\hline Pn-3-Glc & $48.60 \pm 2.06 a$ & $55.75 \pm 16.73 a$ & $63.24 \pm 4.63 \mathrm{a}$ & $60.26 \pm 13.99 a$ \\
\hline Mv-3-Glc & $692.48 \pm 67.40 b$ & $799.08 \pm 68.06 b$ & $783.91 \pm 75.85 b$ & $536.54 \pm 67.39 a$ \\
\hline Total non-acylated & $1219.33 \pm 108.11 b$ & $1305.79 \pm 92.17 b$ & $1271.74 \pm 144.91 b$ & $910.48 \pm 170.71 a$ \\
\hline Df-3-Acglc & $14.37 \pm 1.01 \mathrm{a}$ & $15.83 \pm 1.12 \mathrm{a}$ & $15.03 \pm 2.44 \mathrm{a}$ & $12.25 \pm 2.04 \mathrm{a}$ \\
\hline Cn-3-Acglc & $5.37 \pm 0.08 \mathrm{a}$ & $5.56 \pm 0.26 \mathrm{a}$ & $5.43 \pm 0.30 \mathrm{a}$ & $5.00 \pm 0.45 \mathrm{a}$ \\
\hline Pt-3-Acglc & $13.57 \pm 0.60 \mathrm{ab}$ & $14.99 \pm 1.46 b$ & $13.55 \pm 1.78 \mathrm{ab}$ & $11.38 \pm 1.38 \mathrm{a}$ \\
\hline Pn-3-Acglc & $4.87 \pm 0.12 \mathrm{a}$ & $5.08 \pm 0.28 \mathrm{a}$ & $4.82 \pm 0.54 \mathrm{a}$ & $5.55 \pm 0.30 \mathrm{a}$ \\
\hline Mv-3-Acglc & $33.45 \pm 2.59 \mathrm{a}$ & $46.16 \pm 3.01 \mathrm{~b}$ & $41.86 \pm 3.80 \mathrm{~b}$ & $34.33 \pm 1.55 \mathrm{a}$ \\
\hline Total acetylated & $71.64 \pm 4.02 \mathrm{a}$ & $87.63 \pm 5.92 b$ & $80.70 \pm 8.69 \mathrm{ab}$ & $68.51 \pm 5.72 \mathrm{a}$ \\
\hline Df-3-Cmglc & $61.31 \pm 8.25 \mathrm{a}$ & $53.48 \pm 12.99 a$ & $46.82 \pm 5.46 \mathrm{a}$ & $46.45 \pm 2.76 a$ \\
\hline Cn-3-Cmglc & $10.91 \pm 0.93 \mathrm{a}$ & $9.87 \pm 1.44 a$ & $12.44 \pm 1.32 \mathrm{a}$ & $9.59 \pm 1.76 \mathrm{a}$ \\
\hline Pt-3-Cmglc & $60.15 \pm 7.18 \mathrm{a}$ & $56.48 \pm 11.36 \mathrm{a}$ & $48.99 \pm 6.11 \mathrm{a}$ & $47.28 \pm 1.61 \mathrm{a}$ \\
\hline Pn-3-Cmglc & $22.43 \pm 1.94 \mathrm{a}$ & $25.60 \pm 1.64 a$ & $30.58 \pm 2.88 b$ & $25.81 \pm 2.19 a$ \\
\hline Mv-3-Cmglc & $272.22 \pm 32.13 \mathrm{a}$ & $296.68 \pm 38.17 \mathrm{a}$ & $304.47 \pm 42.61 \mathrm{a}$ & $268.97 \pm 7.36 \mathrm{a}$ \\
\hline Mv-3-Cis-Cmglc & $11.42 \pm 0.41 \mathrm{a}$ & $13.92 \pm 0.71 b$ & $12.47 \pm 1.16 \mathrm{ab}$ & $11.15 \pm 0.50 \mathrm{a}$ \\
\hline Total coumaroylated & $438.45 \pm 49.71 \mathrm{a}$ & $456.03 \pm 61.13 a$ & $455.78 \pm 55.83 a$ & $409.25 \pm 0.47 \mathrm{a}$ \\
\hline Mv-3-Cfglc & $5.38 \pm 0.42 \mathrm{a}$ & $6.59 \pm 0.57 b$ & $5.08 \pm 0.19 \mathrm{a}$ & $4.81 \pm 0.09 \mathrm{a}$ \\
\hline Total anthocyanins & $1734.79 \pm 161.49 b$ & $1856.03 \pm 32.45 b$ & $1813.30 \pm 149.45 b$ & $1393.05 \pm 176.82 \mathrm{a}$ \\
\hline
\end{tabular}

All parameters are given with their standard deviation $(n=3)$. Different letters in the same row indicate significant differences $(\mathrm{p} \leq 0.05)$ among the sites.

Df: Delphinidin; Cn: cyanidin; Pt: petunidin; Pn: peonidin; Mv: malvidin; glc: glucoside; Acglc: acetyl-glucoside; Cfglc: caffeoyl-glucoside; Cmglc: p-coumaroyl-glucoside. 


\section{Grape non-anthocyanins content}

Table 3 shows grape non-anthocyanins concentration from 'Carignan' vineyards grafted onto 'País' rootstock along Maule Valley (Chile). The most abundant flavonol was quercetin-3-glc+rutin, ranging from 36.29 to $66.67 \mathrm{mg} \mathrm{kg}^{-1}$ (Val and Lon sites, respectively). Total flavonols concentration in the samples varied from 124.17 to $218.93 \mathrm{mg} \mathrm{kg}^{-1}$ (Val and Lon sites, respectively). The most abundant flavanol in 'Carignan' grapes was catechin, ranging from 25.78 to $50.58 \mathrm{mg}$ $\mathrm{kg}^{-1}$ (Mel and Val sites, respectively). Total flavanols concentration varied from 86.85 to $158.13 \mathrm{mg} \mathrm{kg}^{-1}$ (Lon and Val sites, respectively). The most abundant HCA found in the samples was trans-caftaric acid varying from 15.32 to 22.38 $\mathrm{mg} \mathrm{kg}^{-1}$ (Mel and Hdm sites, respectively). Total content of HCAs varied from 23.91 to $34.84 \mathrm{mg} \mathrm{kg}^{-1}$ (Mel and $\mathrm{Hdm}$ sites, respectively). The grapes from Lon presented the highest concentration of quercetin derivatives and total flavonols, while the grapes from Val showed the lowest concentration of most of the myricetin derivatives and lower content of several flavonols than the berries from the most of the sites. Respect to the concentration of flavanols in grapes from 'Carignan' grapevines grafted onto 'País' rootstock, Val samples presented the highest procyanidin B1, catechin and total flavanols, while Lon berries showed lower content of procyanidin B1, epicatechin and epicatechin gallate than the samples from the most of the sites. The concentration of individual hydroxycinnamic acids (HCAs) did not showed differences among the sites, as its total concentration. According to the exposed by Martínez-Gil et al. (2018) in 'Carignan' ungrafted vineyards, the concentration of total anthocyanins and flavonols was correlated with the accumulation of biologically effective degree days. These authors showed that a high total flavanols and HCAs concentration was related with the coldest sites. Contrary to these results, Cohen et al. (2012) showed that in a study of $2 \mathrm{yr}$, cooling berries resulting in a significant increase in the proportion of epigallocatechins in grapes.

Table 3. Grape non-anthocyanins content from 'Carignan' vineyards grafted onto 'País' rootstock along Maule Valley (Chile): Valdivia (Val), Loncomilla (Lon), Melozal (Mel), and Huerta de Maule (Hdm).

\begin{tabular}{|c|c|c|c|c|}
\hline Flavonols & Lon & Mel & $\mathrm{Hdm}$ & Val \\
\hline & \multicolumn{4}{|c|}{$-\mathrm{mg} \mathrm{kg}^{-1}$} \\
\hline Myricetin-3-Glucu & $2.92 \pm 0.06 \mathrm{ab}$ & $3.24 \pm 1.18 b$ & $2.25 \pm 0.46 \mathrm{ab}$ & $1.18 \pm 0.11 \mathrm{a}$ \\
\hline Myricetin-3-Gal & $7.40 \pm 1.09 b$ & $6.87 \pm 1.52 b$ & $5.59 \pm 0.43 b$ & $3.30 \pm 0.61 \mathrm{a}$ \\
\hline Myricetin-3-Glc & $55.96 \pm 8.29 b$ & $53.78 \pm 11.41 \mathrm{~b}$ & $44.92 \pm 2.35 b$ & $26.90 \pm 4.41 \mathrm{a}$ \\
\hline Quercetin-3-Glucu & $57.07 \pm 0.15 b$ & $36.75 \pm 8.32 \mathrm{a}$ & $36.55 \pm 4.07 \mathrm{a}$ & $40.70 \pm 7.04 \mathrm{a}$ \\
\hline Quercetin-3-Glc+Rut & $66.67 \pm 3.02 b$ & $38.21 \pm 10.70 \mathrm{a}$ & $48.89 \pm 5.30 \mathrm{a}$ & $36.29 \pm 5.16 \mathrm{a}$ \\
\hline Laricitrin-3-Glc & $6.52 \pm 0.90 b$ & $6.96 \pm 1.24 b$ & $5.86 \pm 0.21 b$ & $3.88 \pm 0.68 \mathrm{a}$ \\
\hline Kaempferol-3-Glc & $16.06 \pm 0.13 b$ & $8.45 \pm 2.63 \mathrm{a}$ & $11.02 \pm 2.80 \mathrm{ab}$ & $8.20 \pm 1.83 a$ \\
\hline Isorhamnetin-3-Glc & $3.58 \pm 0.41 \mathrm{c}$ & $2.32 \pm 0.55 \mathrm{ab}$ & $3.25 \pm 0.52 b c$ & $2.00 \pm 0.14 \mathrm{a}$ \\
\hline Syringetin-3-Glc & $2.74 \pm 0.33 b$ & $2.80 \pm 0.42 b$ & $2.25 \pm 0.17 \mathrm{ab}$ & $1.73 \pm 0.43 \mathrm{a}$ \\
\hline Total flavonols & $218.93 \pm 13.82 b$ & $159.37 \pm 37.97 \mathrm{a}$ & $160.58 \pm 10.38 \mathrm{a}$ & $124.17 \pm 7.85 \mathrm{a}$ \\
\hline \multicolumn{5}{|l|}{ Flavanols } \\
\hline Procyanidin B1 & $16.06 \pm 3.09 \mathrm{a}$ & $17.97 \pm 4.13 \mathrm{a}$ & $16.46 \pm 1.40 \mathrm{a}$ & $29.21 \pm 3.00 b$ \\
\hline Procyanidin B2 & $7.161 \pm 1.71 \mathrm{a}$ & $13.53 \pm 4.64 b$ & $8.52 \pm 0.21 \mathrm{ab}$ & $13.00 \pm 1.68 b$ \\
\hline Catechin & $25.80 \pm 7.21 \mathrm{a}$ & $27.53 \pm 10.18 \mathrm{a}$ & $25.78 \pm 3.55 \mathrm{a}$ & $50.58 \pm 6.00 \mathrm{~b}$ \\
\hline Epicatechin & $10.40 \pm 1.80 \mathrm{a}$ & $20.07 \pm 4.61 b c$ & $13.8 \pm 0.34 \mathrm{ab}$ & $26.02 \pm 5.05 \mathrm{c}$ \\
\hline Epicatechin gallate & $22.34 \pm 3.38 \mathrm{a}$ & $27.76 \pm 6.02 \mathrm{ab}$ & $19.67 \pm 4.20 \mathrm{a}$ & $35.39 \pm 5.49 b$ \\
\hline Epigallocatechin & $5.10 \pm 1.49 \mathrm{ab}$ & $7.21 \pm 2.66 b$ & $4.18 \pm 0.48 \mathrm{ab}$ & $3.93 \pm 0.46 \mathrm{a}$ \\
\hline Total flavanols & $86.85 \pm 17.94 a$ & $114.08 \pm 31.20 \mathrm{a}$ & $88.50 \pm 8.77 \mathrm{a}$ & $158.13 \pm 14.01 \mathrm{~b}$ \\
\hline \multicolumn{5}{|l|}{ Hydroxycinnamic acids } \\
\hline trans-Caftaric & $15.93 \pm 4.08 \mathrm{a}$ & $15.32 \pm 2.46 \mathrm{a}$ & $22.38 \pm 1.05 \mathrm{a}$ & $18.26 \pm 5.53 \mathrm{a}$ \\
\hline trans+cis-Coutaric & $7.54 \pm 2.12 \mathrm{a}$ & $7.75 \pm 2.21 \mathrm{a}$ & $11.54 \pm 1.42 \mathrm{a}$ & $11.07 \pm 2.54 \mathrm{a}$ \\
\hline Caffeic acid & $0.89 \pm 0.01 \mathrm{ab}$ & $0.84 \pm 0.03 \mathrm{a}$ & $0.92 \pm 0.03 b$ & $0.86 \pm 0.04 \mathrm{ab}$ \\
\hline Total HCAs & $24.36 \pm 6.15 a$ & $23.91 \pm 4.65 a$ & $34.84 \pm 2.44 \mathrm{a}$ & $30.19 \pm 8.04 \mathrm{a}$ \\
\hline
\end{tabular}

All parameters are given with their standard deviation $(n=3)$. Different letters in the same row indicate significant differences $(\mathrm{p} \leq 0.05)$ among the sites.

glc: Glucoside; glucu: glucuronide; gal: galactoside; rut: rutin; HCAs: hydroxycinnamic acids. 


\section{CONCLUSIONS}

Climate and soil conditions affected must oenological parameters and phenolic composition of 'Carignan' grapevines grafted onto País variety. The grapes from Valdivia presented the lowest total anthocyanins concentration and the highest total flavanols content. The grape berries from Loncomilla showed the highest total flavonols content. Total hydroxycinnamic acids concentration was not affected by the different locations. The importance of this work is to give knowledge about the effect of climate conditions and soil characteristics on grape phenolic composition of 'Carignan' grapevines grafted onto 'País'. This may be useful for the viticultural managing of the Chilean 'Carignan' vineyards with the aim to improve grape quality and the income of small wine-growers of Maule Valley.

\section{ACKNOWLEDGEMENTS}

This work was funded by FIC BIP 30.345.677-0 and VIGNO (Vignadores de Carignan). G.G.-G. thanks for the financial support given by CONICYT, BCH/Doctorado-72170532.

\section{REFERENCES}

Andrés-de Prado, R., Yuste-Rojas, M., Sort, X., Andrés-Lacueva, C., Torres, M., and Lamuela-Raventós, R.M. 2007. Effect of soil type on wines produced from Vitis vinifera L. cv. Grenache in commercial vineyards. Journal of Agricultural and Food Chemistry 55:779-786. doi:10.1021/jf062446q.

Castillo-Muñoz, N., Gómez-Alonso, S., García-Romero, E., and Hermosín-Gutiérrez, I. 2007. Flavonol profiles of Vitis vinifera red grapes and their single-cultivar wines. Journal of Agricultural and Food Chemistry 55:992-1002. doi:10.1021/jf062800k.

Cohen, S.D., Tarara, J.M., Gambetta, G.A., Matthews, M.A., and Kennedy, J.A. 2012. Impact of diurnal temperature variation on grape berry development, proanthocyanidin accumulation, and the expression of flavonoid pathway genes. Journal of Experimental Botany 63:2655-2665. doi:10.1093/jxb/err449.

Edo-Roca, M., Nadal, M., and Lampreave, M. 2013. How terroir affects bunch uniformity, ripening and berry composition in Vitis vinifera cvs. Carignan and Grenache. Journal International des Sciences de la Vigne et du Vin 47:1-20. doi:10.20870/ oeno-one.2013.47.1.1533.

Gutiérrez-Gamboa, G., Carrasco-Quiroz, M., Martínez-Gil, A.M., Pérez-Álvarez, E.P., Garde-Cerdán, T., and MorenoSimunovic, Y. 2018a. Grape and wine amino acid composition from Carignan noir grapevines growing under rainfed conditions in the Maule Valley, Chile: Effects of location and rootstock. Food Research International 105:344-352. doi:https:// doi.org/10.1016/j.foodres.2017.11.021.

Gutiérrez-Gamboa, G., Verdugo-Vásquez, N., Carrasco-Quiroz, M., Garde-Cerdán, T., Martínez-Gil, A.M., and MorenoSimunovic, Y. 2018b. Carignan phenolic composition in wines from ten sites of the Maule Valley (Chile): Location and rootstock implications. Scientia Horticulturae 234:63-73. doi:doi.org/10.1016/j.scienta.2018.02.013.

Lago-Vanzela, E.S., Da-Silva, R., Gomes, E., García-Romero, E., and Hermosín-Gutiérrez, I. 2011. Phenolic composition of the edible parts (flesh and skin) of Bordô grape (Vitis labrusca) using HPLC-DAD-ESI-MS/MS. Journal of Agricultural and Food Chemistry 59:13136-13146. doi:10.1021/jf203679n.

Martínez-Gil,A., Gutiérrez-Gamboa,G., Garde-Cerdán, T., Pérez-Álvarez, E., and Moreno-Simunovic, Y. 2018.Characterization of phenolic composition in Carignan noir grapes (Vitis vinifera L.) from six wine-growing sites in Maule Valley, Chile. Journal of the Science of Food and Agriculture 98:274-282. doi:10.1002/jsfa.8468.

Moreno, Y., y Vallarino, J. 2011. Manual de consulta de cultivares y portainjertos de vides para vinificación. 96 p. Origo Editores, Santiago, Chile.

OIV. 2003. Compendium of internationals methods of wine and must analysis. Organisation Internationale de la Vigne et du Vin (OIV), Paris, France.

Portu, J., González-Arenzana, L., Hermosín-Gutiérrez, I., Santamaría, P., and Garde-Cerdán, T. 2015. Phenylalanine and urea foliar applications to grapevine: Effect on wine phenolic content. Food Chemistry 180:55-63. doi:10.1016/j. foodchem.2015.02.008.

SAG. 2015. Catastro vitícola nacional. Servicio Agrícola y Ganadero (SAG), Santiago, Chile. Available at http://www.sag.gob. cl/ (accessed November 2017).

Sörensen, S.P.L. 1907. Enzymstudien I: Über die quantitative Messung proteolytischer Spaltungen, Die formoltitrierung. Biochemische Zeitschrift 7:45-101.

van Leeuwen, C., Friant, P., Choné, X., Tregoat, O., Koundouras, S., and Dubourdieu, D. 2004. Influence of climate, soil and cultivar on terroir. American Journal of Enology and Viticulture 55:207-217. 